8 Petry NM. Pathological gamblers, with and without substance use disorders, discount delayed rewards at high rates. J Abnorm Psychol 2001; 110: 482-7.

9 Goudriaan $A E$, Oosterlaan J, de Beurs $E$, van den Brink W. Neurocognitive functions in pathological gambling: a comparison with alcohol dependence, Tourette syndrome and normal controls. Addiction 2006; 101: 534-47.

10 Bowden-Jones $\mathrm{H}$, McPhillips M, Rogers R, Hutton S, Joyce E. Risk-taking on tests sensitive to ventromedial prefrontal cortex dysfunction predicts early relapse in alcohol dependency: a pilot study. J Neuropsychiatry Clin Neurosci 2005; 17: 417-20.

11 Potenza MN. The neurobiology of pathological gambling and drug addiction: an overview and new findings. Philos Trans R Soc Lond B Biol Sci 2008; 363 : 3181-9.

12 Reuter J, Raedler T, Rose M, Hand I, Glascher J, Buchel C. Pathological gambling is linked to reduced activation of the mesolimbic reward system. Nat Neurosci 2005; 8: 147-8.

13 Campbell-Meiklejohn DK, Woolrich MW, Passingham RE, Rogers RD. Knowing when to stop: the brain mechanisms of chasing losses. Biol Psychiatry 2008; 63: 293-300.

14 Blaszczynski A, Nower L. A pathways model of problem and pathological gambling. Addiction 2002; 97: 487-99.
15 Toce-Gerstein M, Gerstein DR, Volberg RA. A hierarchy of gambling disorders in the community. Addiction 2003; 98: 1661-72.

16 Wardle H, Sproston K, Erens B, Orford J, Griffiths M, Constantine R, et al. British Gambling Prevalence Survey 2007. National Centre for Social Research, 2007.

17 Strong DR, Kahler CW. Evaluation of the continuum of gambling problems using the DSM-IV. Addiction 2007; 102: 713-21.

18 Kessler RC, Hwang I, LaBrie R, Petukhova M, Sampson NA, Winters KC, et al. DSM-IV pathological gambling in the National Comorbidity Survey Replication. Psychol Med 2008; 38: 1351-60.

19 Shaffer HJ, Hall MN, Vander Bilt J. Estimating the prevalence of disordered gambling behavior in the United States and Canada: a research synthesis. Am J Public Health 1999; 89: 1369-76.

20 Wardle H, Moody A, Spence S, Orford J, Volberg R, Jotangia D, et al. British Gambling Prevalence Survey 2010. National Centre for Social Research, 2011.

21 Gooding P, Tarrier N. A systematic review and meta-analysis of cognitivebehavioural interventions to reduce problem gambling: hedging our bets? Behav Res Ther 2009; 47: 592-607.

22 Block JJ. Issues for DSM-V: internet addiction. Am J Psychiatry 2008; 165: 306-7.

\title{
Reading for well-being
}

\section{David Fearnley}

Patients and carers tell us about themselves using stories. Indeed, psychiatry prides itself on its ability to listen carefully and then to record these stories (or histories). What is less well developed is the use of fiction, or imaginary narrative, to improve health and well-being. Nevertheless, we may quietly turn to the greatest writers, expecting them to entertain but also guide us towards feeling better about ourselves. Books are often readily available, portable and inexpensive. Reading can offer a chance for self-discovery and self-help, and is a unique emotional and cognitive experience that should be of major interest to psychiatry. 